\title{
フレキキジルアームの仮想受動関節モデルに基つくく制御系の一設計法*
}

\author{
大川 不二夫*1, 小 林順*1 \\ 小川裕 文*2, 本田英 已*3
}

\section{A Control Method Based on Virtual Joint Model of a Flexible Arm}

\author{
Fujio OHKAWA*4, Jun KOBAYASHI, \\ Hirofumi OGAWA and Hideki HONDA \\ ${ }^{* 4}$ Department of Control Engineering, Kyushu Institute of Technology, \\ 680-4 Kawazu, Iizuka-shi, Fukuoka, 820-8502 Japan
}

\begin{abstract}
This paper proposes a control method of a flexible arm using virtual joint model. The virtual joint model of a flexible arm has many parameters that have to identify from measured dynamic and static characteristics. An adaptive control scheme is introduced to avoid a difficulty and complexity of this identification. But, a model reference adaptive control system cannot be applied for a tip position control of a flexible arm due to its non-minimum phase characteristic. Then, we designed an adaptive-type predictive control system to achieve the tip position control. Simulation and experimental results demonstrate an effectiveness of the proposed control system.
\end{abstract}

Key Words: Flexible Arm, Virtual Joint Model, Adaptive Control, Adaptive-Type Predictive Control

\section{1. まえがき}

作業の高速化，省エネルギー化のために軽量化され たマニピュレータは, その剛性の低さからきしみ振動 を生じる。この例に代表されるように,フレキシブル マニピュレータなどフレキシブルシステムの振動の抑 制については数多くの研究がなされている(1) (6). ま ず, 制御系設計の前提として必要となるフレキシブル マニピュレータのモデリング法に関しては, 集中定数 系によるモデリング法が数多く提案されてい る(6) (8). 吉川らは, 集中定数系モデルの一つとして, 仮想受動関節モデルを提案し，このモデルが分布定数 系モデルと同程度の精度を持たせえることを示し た ${ }^{(8)}$.このモデルは, 分布定数系モデルと比較すると 簡綮であるために，制御系設計がより容易に実現可能 と考えられるが，このモデルパラメータには多くの自 由度があり，その決定には試行錯誤が要求される。 の結果, このモデルを用いた制御系設計に関しては,

* 原稿受付 2001 年 4 月 23 日.

*1 正員, 九州工業大学情報工学部(画820-8502 飯塚市川津 680-4).

*2 九州工業大学大学院

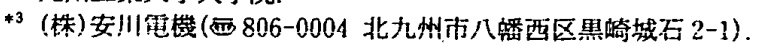

E-mail : ohkawa@ces.kyutech.ac.jp
今のところ報告は見られない。

本論文では，まず, 仮想受動関節モデルを用いた適 応制御系の設計法を示した。すなわち，仮想受動関節 モデルの制御系設計に用いる場合の問題点と考えられ るモデルパラメータ決定に関して, パラメータをリア ルタイムで調整することにより制御目的を達成する適 応制御系 ${ }^{(9)}$ を導入することにより解決できることを 示した. 次に, 設計した制御系の有効性をシミュレー ションと実験により確認した。なお，モデル規範形適 応制御系は逆ダイナミクスに基づいた設計手法である ため, 先端位置制御には適用できない。すなわち、フ レキシブルアームにおいては, 関節トルクに対する関 節角度のダイナミクスは最小位相系となるが, 先端位 置のダイナミクスは非最小位相系となるためであ る(10). したがって, 先端位置制御においては, 制御対 象が非最小位相系である場合でも適用可能である適応 形予測制御系(11)(12) を設計するとともに，実験装置に より実験を行った。その結果, 比較的簡潔な制御系構 成でもって，良好な制御性能が得られ，提案した制御 系の有効性が確認された。

\section{2. 適 応制 御}

ここでは，モデル規範形適応制御系を設計し，その 
有効性を確認する。

$2 \cdot 1$ モテリングここで対象とする1リンクフ レキシブルアーム系のモデル図は図 1 である。関節に 加えられるトルクを $\tau_{1}$, 関節角度を $\phi_{1}$ とする.また， 先端に取付けられたぺイロードの重心位置 $\left(x_{e}, y_{e}\right)$ と 慣性座標系の原点を結ぶ直線の角度 (以下では先端位 置角度と呼ぶ)を $\phi_{e}$ とする。

仮想受動関節モデルによるモデリングは，ばね，ダ ンパの仮想受動関節によって結合されたリンクの連結 により,フレキシブルアームを近似する方法である。

図1のフレキシブルアームを仮想受動関節を用いて モデル化した例を図 2 に示す。なお，ここでは簡単化 のため, 同じ長さの 2 本の仮想剛体リンクと 1 個の仮 想受動関節でモデリングした。また， $\phi_{v 1}$ は仮想受動 関節角度であり，次式により求める。

$$
\phi_{v 1}=2\left(\arctan \left(\frac{y_{e}}{x_{e}}\right)-\phi_{1}\right)
$$

なお，必要とされるリンクの本数は柔軟性に依存する が，これらの定量的な決定法はいまのところ明らかで はない.

図 2 で示したモデルの運動方程式を導出すると次式 を得る。

$$
\left[\begin{array}{ll}
M_{11} & M_{12} \\
\dot{M}_{21} & M_{22}
\end{array}\right]\left[\begin{array}{c}
\ddot{\phi}_{1} \\
\ddot{\phi}_{v 1}
\end{array}\right]+\left[\begin{array}{c}
H_{1} \\
H_{2}
\end{array}\right]=\left[\begin{array}{c}
\tau \\
-d_{v 1} \dot{\phi}_{v 1}-k_{v 1} \phi_{v 1}
\end{array}\right]
$$

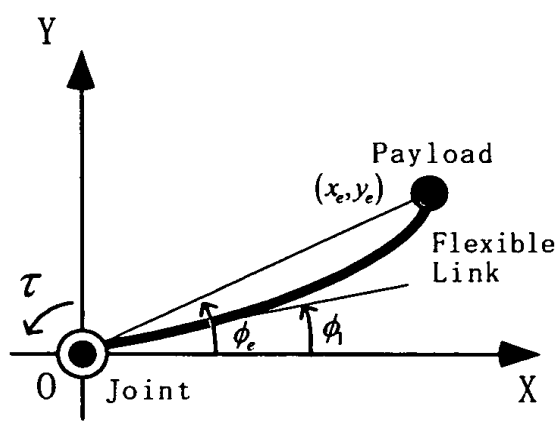

Fig. 1 Flexible Arm

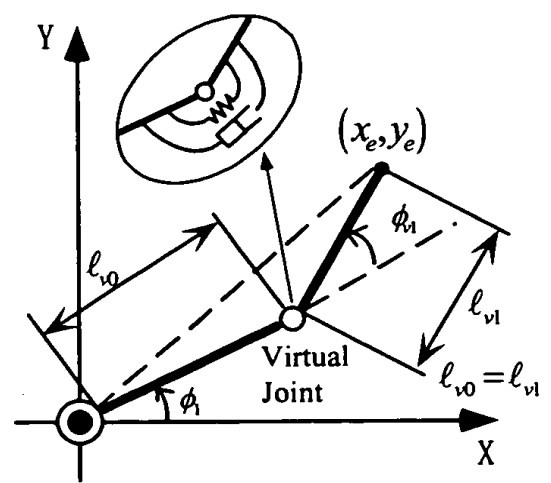

Fig. 2 Virtual Joint Model
ただし，

$$
\begin{aligned}
& M_{11}=J_{1}+J_{2}+2 \alpha \cos \phi_{v 1}, \\
& M_{12}=M_{21}=J_{2}+\alpha \cos \phi_{v 1}, M_{22}=J_{2} \\
& H_{1}=-\alpha \dot{\phi}_{v 1}\left\{2 \dot{\phi}_{1}+\dot{\phi}_{v 1}\right\} \sin \phi_{v 1}, H_{2}=\alpha \dot{\phi}_{1}^{2} \sin \phi_{v 1} \\
& J_{1}=I_{c v 0}+m_{v 0} l_{g v 0}^{2}+m_{v 1} l_{v 0}^{2}, J_{2}=I_{c v 1}+m_{v 1} l_{g v 1}^{2}, \\
& \alpha=m_{v 1} l_{v 0} l_{g v 1}
\end{aligned}
$$

$\phi_{1}:$ アーム関節角度 $\phi_{v 1}$ : 仮想受動関節角度 $\tau$ :入力トルク $d_{v 1}$ : 仮想受動関節のダンピング係数 $k_{v 1}$ : 仮想受動関節のばね係数 $m_{v 0}, m_{v 1}:$ 仮想剛体リンクの質量 $l_{v 0}, l_{v 1}:$ 仮想剛体リンクの長さ $l_{g v 0}, l_{g v 1}:$ 各リンク質量中心までの距離 $I_{c v 0}, I_{c v 1}$ : 各リンクの質量中心周りの慣性モーメント である。

式（2）を用いて離散化すると，次式が得られる。

$$
\tau(k)=\boldsymbol{Y}(k+1) \boldsymbol{\sigma}
$$

ただし，

$$
\begin{aligned}
& \boldsymbol{Y}=\left[\begin{array}{lllllll}
y_{1} & y_{2} & y_{3} & y_{4} & y_{5} & y_{6} & y_{7}
\end{array}\right]: \text { 回帰ベクトル }
\end{aligned}
$$

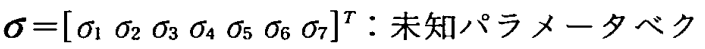

$$
\begin{aligned}
& \text { トル } \\
& y_{1}(k)=\frac{\phi_{1}(k+1)-2 \phi_{1}(k)+\phi_{1}(k-1)}{T^{2}} \\
& =\Delta^{2} \phi_{1}(k+1) \\
& y_{2}(k)=-\cos \phi_{v 1}(k)\left[\cos \phi_{v 1}(k) \cdot \Delta^{2} \phi_{1}(k+1)\right. \\
& \left.+\sin \phi_{v_{1}}(k) \cdot\left\{\Delta \phi_{1}(k)\right\}^{2}\right] \\
& y_{3}(k)=-\sin \phi_{v 1}(k)\left[\left\{\Delta \phi_{1}(k)\right\}^{2}\right. \\
& \left.+\Delta \phi_{v_{1}}(k) \cdot\left\{2 \Delta \phi_{1}(k)+\Delta \phi_{v 1}(k)\right\}\right] \\
& y_{4}(k)=-\cos \phi_{v 1}(k) \cdot \Delta \phi_{v 1}(k) \text {, } \\
& y_{5}(k)=-\cos \phi_{v 1}(k) \cdot \phi_{v_{1}}(k) \\
& y_{6}(k)=-\Delta \phi_{v 1}(k), \quad y_{7}(k)=-\phi_{v 1}(k) \\
& \Delta=\frac{1-z^{-1}}{T} \\
& \text { ( } z \text { ：1 サンプリング周期シフト演算子) } \\
& \sigma_{1}=J_{1}, \quad \sigma_{2}=\frac{\alpha^{2}}{J_{2}}, \quad \sigma_{3}=\alpha, \sigma_{4}=\frac{\alpha d_{v 1}}{J_{2}}, \\
& \sigma_{5}=\frac{\alpha k_{v 1}}{J_{2}}, \sigma_{6}=d_{v 1}, \sigma_{7}=k_{v 1}
\end{aligned}
$$

である。

$2 \cdot 2$ 適応則 . 式 (3)の未知パラメータ $\sigma$ を, 可 調整パラメータ $\bar{\sigma}(k)$ で置き換えた同定モデルを

$$
\bar{\tau}_{1}(k)=\boldsymbol{Y}(k+1) \boldsymbol{\sigma}(k+1)
$$

とすると, 入力愦差 $\eta(k)$ は，

$$
\eta(k+1) \triangleq \bar{\tau}_{1}(k)-\tau_{1}(k)=Y(k+1)\{\hat{\sigma}(k+1)-\sigma\}
$$

となる。式(5)は誤差方程式の一般形であるので, 種々の適応アルゴリズムにより, $k \rightarrow \infty$ に対し, $\eta(k$ 
$+1) \rightarrow 0$ と $\bar{\sigma}(k+1)-\widehat{\sigma}(k) \rightarrow 0$ が保証される(9).

次に, $Y(k+1)$ に含まれる $\phi_{1}(k)$ の末来值 $\phi_{1}(k$ $+1)$ を目標值 $\phi_{1 d}(k+1)$ で置き換えたものを $Y_{d}(k$ +1)とし, 制御入力を次式で合成する.

$$
\begin{aligned}
& \tau_{1}(k)=\sigma_{1}(k) \cdot \frac{\phi_{1 d}(k+1)-2 \phi_{1}(k)+\phi_{1}(k-1)}{T^{2}} \\
& -\widehat{\sigma}_{2}(k)\left\{\cos ^{2} \phi_{v 1}(k)\right. \\
& \times \frac{\phi_{1 d}(k+1)-2 \phi_{1}(k)+\phi_{1}(k-1)}{T^{2}} \\
& \left.+\cos \phi_{v 1}(k) \sin \phi_{v 1}(k)\left\{\Delta \phi_{1}(k)\right\}^{2}\right\} \\
& -\widehat{\sigma}_{3}(k)\left\{\sin \phi_{v 1}(k)\left\{\Delta \phi_{1}(k)\right\}^{2}\right. \\
& \left.+\sin \phi_{v_{1}}(k) \Delta \phi_{v_{1}}(k)\left\{2 \Delta \phi_{1}(k)+\Delta \phi_{v_{1}}(k)\right\}\right\} \\
& -\widehat{\sigma}_{4}(k) \cos \phi_{v 1}(k) \Delta \phi_{v 1}(k) \\
& -\bar{\sigma}_{5}(k) \cos \phi_{v 1}(k) \phi_{v 1}(k) \\
& -\widehat{\sigma}_{6}(k) \Delta \phi_{v 1}(k)-\widehat{\sigma}_{7}(k) \phi_{v 1}(k)-K e(k) \\
& =Y_{d}(k+1) \boldsymbol{\sigma}(k)-K e(k) \\
& e(k)=\phi_{1 d}(k)-\phi_{1}(k)
\end{aligned}
$$

ただし， $K$ はフィードバックゲインである.

式 (4)と (6)より, 入力誤差方程式は次式となる.

$$
\begin{aligned}
& \eta(k+1)=\boldsymbol{Y}(k+1)\{\boldsymbol{\sigma}(k+1)-\boldsymbol{\sigma}(k)\} \\
& -\frac{\widehat{\sigma}_{1}(k)-\widehat{\sigma}_{2}(k) \cos ^{2} \phi_{v 1}(k)}{T^{2}} e(k+1)+K e(k)
\end{aligned}
$$

$k \rightarrow \infty に$ 対して, 適応アルゴリズムにより $+1) \rightarrow 0$ と $\widehat{\sigma}(k+1)-\bar{\sigma}(k) \rightarrow 0$ が保証されているの で,

Table 1 Physical Parameters

\begin{tabular}{|c|c|}
\hline Length $(\mathrm{m})$ & 0.5500 \\
\hline Linear Density $(\mathrm{kg} / \mathrm{m})$ & 0.3140 \\
\hline Young's Modulus $\left(\mathrm{N} / \mathrm{m}^{2}\right)$ & $2.060 \times 10^{11}$ \\
\hline Polar Moment of Inertia of $\mathrm{Area}\left(\mathrm{m}^{4}\right)$ & $3.333 \times 10^{-11}$ \\
\hline Damping Coefficient $\left(\mathrm{Nm}^{3} \mathrm{~s} / \mathrm{kg}\right)$ & $2.080 \times 10^{-4}$ \\
\hline
\end{tabular}

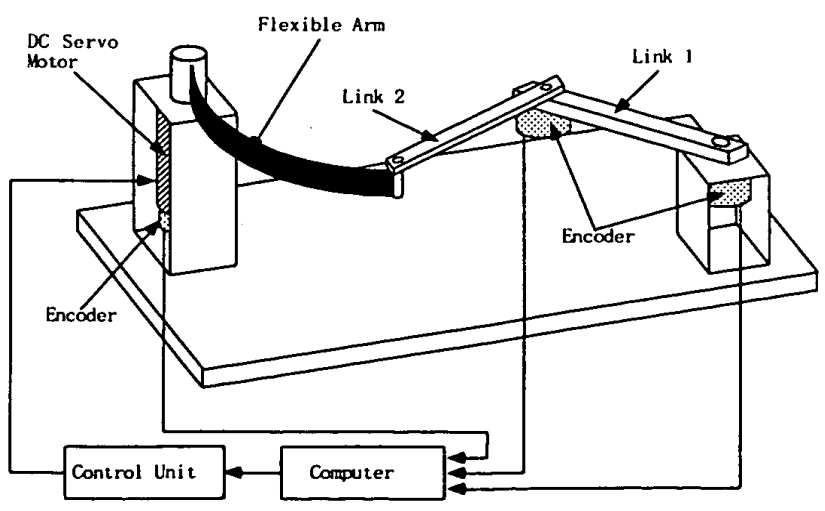

Fig. 3 Schematic Diagram of Experimental Apparatus

$$
\frac{\bar{\sigma}_{1}(k)+\bar{\sigma}_{2}(k) \cos ^{2} \phi_{\nu 1}(k)}{T^{2}} e(k+1)-K e(k) \rightarrow 0
$$

が成り立つ.したがって，フィードバックゲイン $K$

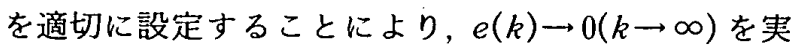
現できる。

$2 \cdot 3$ シミュレーションおよび実験 シミュレー ションおよび実験により構成した適応制御系の有効性 を検証した，なお，用いた適応則は，最小二乗法形で， フィードバックゲイン $K$ は 10 である。また，実験装 置の概念図を図 3 に示す。このときのフレキシブルア ームのパラメータを表 1 に示す. ペイロードは質量 $0.1979(\mathrm{~kg})$ の質点, サンプリング周期は $0.01 \mathrm{~s}$ とし た.
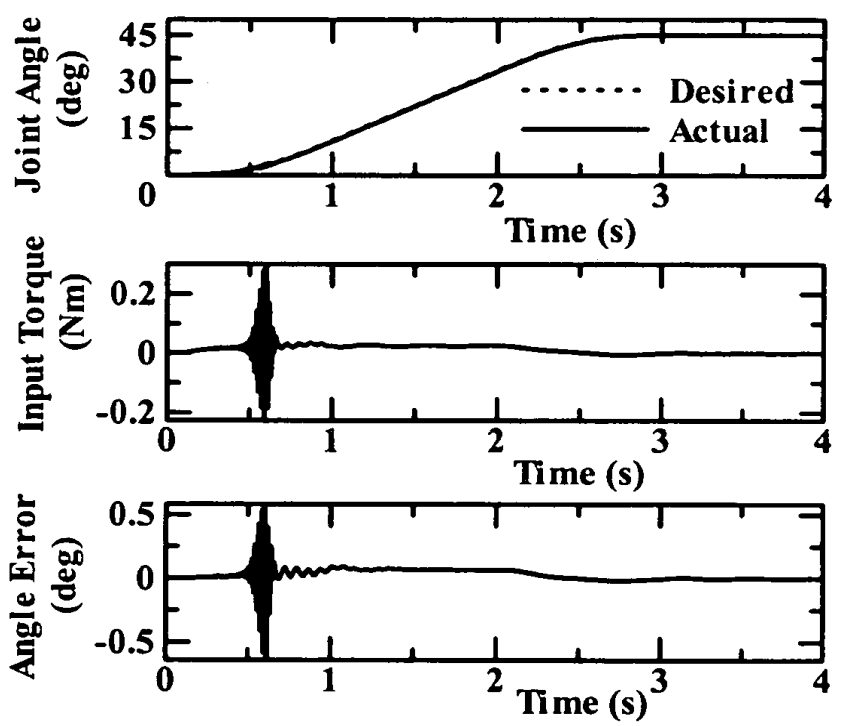

Fig. 4 Simulation Result
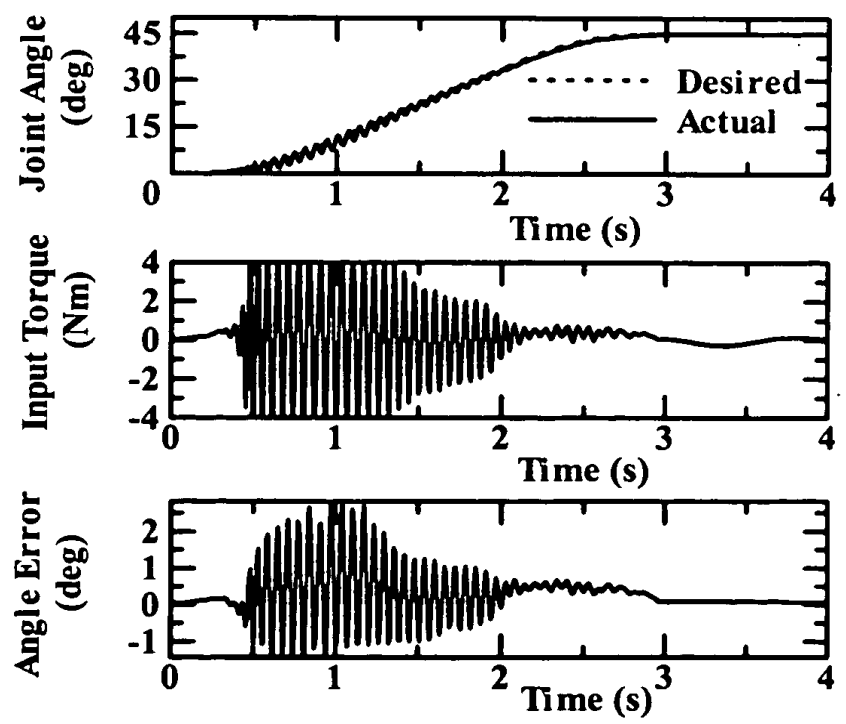

Fig. 5 Experimental Result 
すなわち,サーボモータの駆動軸に一端を固定され， 水平面内を回転するフレキシブルアームの先端に, 位 置検出用 2 リンクアームが連結されているものとす る.ただし，連結はこれらが一つの軸を共有し，その 軸周りに自由に回転するような状態にある,いわゆる 回転対偶であるとする. 従って，フレキシブルアーム は 2 リンクアームに対して力を与えることはできるが トルクを与えることはできない状態にある，また，こ の 2 リンクアームにはそれぞれのアームの回転角度を 検出するエンコーダが取付けられており，それらによ りフレキシブルアームの先端位置を検出する構成にな っている.シミュレーション結果を図 4 , 実験結果を 図 5 に示す.

図 4 と 5 では, 適応アルゴリズムでパラメータが調 整されることにより, 関節角度が目標值に良好に追従 しており，構成した適応制御系の有効性が確認され た。なお実験（図 5)では, 入力により大きな振動現象 が生じ，その結果関節角度の過渡特性に振動がみられ る.これは駆動部の静止摩擦の影響によるものと考え る.

\section{3. 適応形予測制御}

ここでは予測制御系を設計し，その有効性を確認し た.

$3 \cdot 1$ 数式モデルの誘導 図 1 に示す 1 リンクフ レキシブルアームを, 図 6 に示す仮想受動関節モデル により,モデル化した。

ここで, 仮想受動関節角度の変動は十分小さいと仮 定し先端位置角度 $\phi_{e}$ は次式で近似できるとする。

$$
\phi_{e} \cong \phi_{1}+\frac{l_{v 1} \phi_{v 1}+l_{v 2}\left(\phi_{v 1}+\phi_{v 2}\right)}{l_{v 0}+l_{v 1}+l_{v 2}}
$$

仮想受動関節モデルの運動方程式を導出すると次式 を得る。

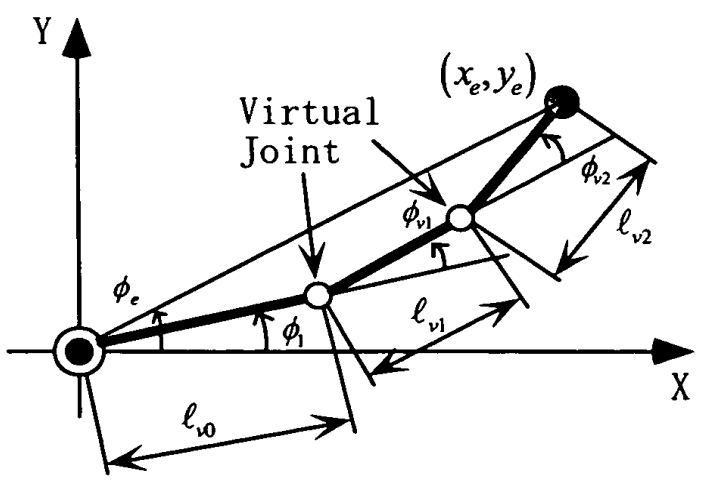

Fig. 6 Virtual Joint Model

$$
\begin{gathered}
{\left[\begin{array}{ccc}
M_{11} & M_{12} & M_{13} \\
M_{21} & M_{22} & M_{23} \\
M_{31} & M_{32} & M_{33}
\end{array}\right]\left[\begin{array}{c}
\ddot{\phi}_{1} \\
\ddot{\phi}_{v 1} \\
\ddot{\phi}_{v 2}
\end{array}\right]+\left[\begin{array}{c}
H_{1} \\
H_{2} \\
H_{3}
\end{array}\right]} \\
\quad=\left[\begin{array}{c}
\tau \\
-d_{v 1} \dot{\phi}_{v 1}-k_{v 1} \dot{\phi}_{v 1} \\
-d_{v 2} \dot{\phi}_{v 2}-k_{v 2} \dot{\phi}_{v 2}
\end{array}\right] \ldots \ldots \ldots .
\end{gathered}
$$

ただし，

$$
\begin{aligned}
& M_{11}=J_{0}+J_{1}+J_{2}+2 \alpha_{1} \cos \phi_{v 1}+2 \alpha_{2} \cos \phi_{v 2} \\
& +2 \alpha_{3} \cos \phi_{v 1}+2 \alpha_{4} \cos \left(\phi_{v 1}+\phi_{v 2}\right)+m_{v 1} l_{v 0}^{2} \\
& +m_{v 2} l_{v 0}^{2}+m_{v 1} l_{v 1}^{2} \\
& M_{12}=M_{21}=J_{1}+J_{2}+\alpha_{1} \cos \phi_{v 1}+2 \alpha_{2} \cos \phi_{v 2} \\
& +\alpha_{3} \cos \phi_{v 1}+\alpha_{4} \cos \left(\phi_{v 1}+\phi_{v 2}\right)+m_{v 2} l_{v 1}^{2} \\
& M_{13}=M_{31}=J_{2}+\alpha_{2} \cos \phi_{v 2}+\alpha_{4} \cos \left(\phi_{v 1}+\phi_{v 2}\right) \\
& M_{22}=J_{1}+J_{2}+2 \alpha_{2} \cos \phi_{v 2}+m_{v 2} l_{v 1}^{2} \\
& M_{23}=M_{32}=J_{2}+\alpha_{2} \cos \phi_{v 2} \\
& M_{33}=J_{2} \\
& H_{1}=\left(-\alpha_{1} \sin \phi_{v 1}-\alpha_{3} \sin \phi_{v 1}\right. \\
& \left.-\alpha_{4} \sin \left(\phi_{v 1}+\phi_{v 2}\right)\right) \dot{\phi}_{v 1}^{2}+\left(\left(-2 \alpha_{2} \sin \phi_{v 2}\right.\right. \\
& \left.-2 \alpha_{4} \sin \left(\phi_{v 1}+\phi_{v 2}\right)\right) \dot{\phi}_{v 2}-2 \alpha_{1} \sin \phi_{v 1} \cdot \dot{\phi}_{1}(t) \\
& \left.-2 \alpha_{4} \sin \left(\phi_{v 1}+\phi_{v 2}\right) \dot{\phi}_{1}-2 \alpha_{3} \sin \phi_{v 1} \cdot \dot{\phi}_{1}\right) \dot{\phi}_{v 1} \\
& +\left(-\alpha_{2} \sin \phi_{v 2}-\alpha_{4} \sin \left(\phi_{v 1}+\phi_{v 2}\right)\right) \dot{\phi}_{v 2}^{2} \\
& +\left(-2 \alpha_{4} \sin \left(\phi_{v 1}+\phi_{v 2}\right) \cdot \dot{\phi}_{1}\right. \\
& \left.-2 \alpha_{2} \sin \phi_{v 2} \cdot \dot{\phi}_{1}\right) \dot{\phi}_{v 2} \\
& H_{2}=-2 \alpha_{2} \sin \phi_{v 2} \cdot \dot{\phi}_{v 2} \dot{\phi}_{v 1}-\alpha_{2} \sin \phi_{v 2} \cdot \dot{\phi}_{v 2}^{2} \\
& +\left(\left(-2 \alpha_{2} \sin \phi_{v 2}-\alpha_{4} \sin \left(\phi_{v 1}+\phi_{v 2}\right)\right) \dot{\phi}_{1}\right. \\
& \left.+\alpha_{4} \sin \left(\phi_{v 1}+\phi_{v 2}\right) \dot{\phi}_{1}\right) \dot{\phi}_{v 2} \\
& -\left(-\alpha_{1} \sin \phi_{v 1}-\alpha_{3} \sin \phi_{v 1}\right. \\
& \left.-\alpha_{4} \sin \left(\phi_{v 1}+\phi_{v 2}\right)\right) \dot{\phi}_{1}^{2} \\
& H_{3}=\alpha_{2} \sin \phi_{v 2} \cdot \dot{\phi}_{v 1}{ }^{2} \\
& +\left(-\left(-2 \alpha_{2} \sin \phi_{v 2}-\alpha_{4} \sin \left(\phi_{v 1}+\phi_{v 2}\right)\right) \cdot \dot{\phi}_{1}\right. \\
& \left.-\alpha_{4} \cdot \sin \left(\phi_{v 1}+\phi_{v 2}\right) \cdot \dot{\phi}_{1}\right) \cdot \dot{\phi}_{v 1} \\
& -\left(-\alpha_{2} \sin \phi_{v 2}-\alpha_{4} \sin \left(\phi_{v 1}+\phi_{v 2}\right)\right) \dot{\phi}_{1}^{2} \\
& J_{0}=I_{c v 0}+m_{v 0} l_{g v 0}^{2}, J_{1}=I_{c v 1}+m_{v 1} l_{g v 1}^{2} \text {, } \\
& J_{2}=I_{c v 2}+m_{v 2} l_{g v 2}^{2} \\
& \alpha_{1}=m_{v 1} l_{v 0} l_{g v 1}, \alpha_{2}=m_{v 2} l_{v 1} l_{g v 2}, \alpha_{3}=m_{v 2} l_{v 0} l_{g v 1} \text {, } \\
& \alpha_{4}=m_{v 2} l_{v 0} l_{g v 2}
\end{aligned}
$$

$\phi_{1}:$ アーム関節角度 $\phi_{v 1}, \phi_{v 2}$ : 仮想受動関節角度 $\tau:$ 入トルク

$d_{v 1}, d_{v 2}:$ 仮想受動関節のダンピング係数

$k_{v 1}, k_{v 2}:$ 仮想受動関節のばね係数

$m_{v 0}, m_{v 1}, m_{v 2}:$ 仮想剛体リンクの質量

$l_{v 0}, l_{v 1}, l_{v 2}:$ 仮想剛体リンクの長さ

$l_{g v 0}, l_{g v 1}, l_{g v 2}:$ 各リンク質量中心までの距離

$I_{c v 0}, I_{c v 1}, I_{c v 2}$ ：各リンクの質量中心周りの慣性モーメ ント

式（9）の近似を用いて, 式(10)における関節角度 $\phi_{1}$ 
を先端位置角度 $\phi_{e}$ に変換し，さらに非線形項を無視 すると，次の運動方程式が得られる。

$$
\begin{gathered}
{\left[\begin{array}{ccc}
\bar{M}_{11} & \bar{M}_{12}-\bar{M}_{11} \beta_{1} & -\bar{M}_{11} \beta_{2}+\bar{M}_{13} \\
\bar{M}_{12} & \bar{M}_{22}-\bar{M}_{12} \beta_{1} & -\bar{M}_{12} \beta_{2}+\bar{M}_{23} \\
\bar{M}_{13} & \bar{M}_{23}-\bar{M}_{13} \beta_{1} & -\bar{M}_{13} \beta_{2}+\bar{M}_{33}
\end{array}\right]\left[\begin{array}{c}
\ddot{\phi}_{e} \\
\ddot{\phi}_{v 1} \\
\ddot{\phi}_{v 2}
\end{array}\right]} \\
\quad=\left[\begin{array}{c}
\tau \\
-d_{v 1} \dot{\phi}_{v 1}-k_{v 1} \phi_{v 1} \\
-d_{v 2} \dot{\phi}_{v 2}-k_{v 2} \phi_{v 2}
\end{array}\right]
\end{gathered}
$$

ただし,

$$
\begin{aligned}
& \bar{M}_{11}=J_{0}+J_{1}+J_{2}+2 \alpha_{1}+2 \alpha_{2}+2 \alpha_{3}+2 \alpha_{4} \\
& \quad+m_{v 1} l_{v 0}^{2}+m_{v 2} l_{v 0}^{2}+m_{v 2} l \\
& \bar{M}_{12}=J_{1}+J_{2}+\alpha_{1}+2 \alpha_{2}+\alpha_{3}+\alpha_{4}+m_{v 2} l_{v 1}^{2} \\
& \bar{M}_{13}=J_{2}+\alpha_{2}+\alpha_{4}, \quad \bar{M}_{22}=J_{1}+J_{2}+2 \alpha_{2}+m_{v 2} l_{v 1}^{2} \\
& \bar{M}_{23}=J_{2}+\alpha_{2}, \quad \bar{M}_{33}=J_{2} \\
& \beta_{1}=\frac{l_{v 1}+l_{v 2}}{l_{v 0}+l_{v 1}+l_{v 2}}, \quad \beta_{2}=\frac{l_{v 2}}{l_{v 0}+l_{v 1}+l_{v 2}}
\end{aligned}
$$

である、

さらに，適応形予測制御系を設計するために必要と なるフレキシブルアームの離散時間モデルを導出す る.

入力トルク $\tau_{1}$ から先端位置角度 $\phi_{e}$ の関数を求める と (11)式を得る.なお, 演算時間として 1 サンプリン グ周期のむだ時間を考慮している.

$$
\phi_{e}(k+1)=Y^{T}(k) \sigma
$$

ただし， $\boldsymbol{Y}(k)$ と $\sigma$ は以下のとおりである.

$$
Y^{T}(k) \triangleq\left[\phi_{e}(k), \cdots, \phi_{e}(k-5), \tau(k-1), \cdots, \tau(k-6)\right]
$$$$
\sigma^{T} \triangleq\left[a_{d 1}, \cdots, a_{d 6}, b_{d 1}, \cdots, b_{d 6}\right]
$$

$a_{d i}, b_{d i}$ : 仮想受動関節モデルから構成されるパラメー 夕

$3 \cdot 2$ 適応形予測制御の概説 適応形予測制御の 基本となっているモデル予測制御は，概念として“制御 量の将来の動きを予測し，その予測する動きが希望と している動きになるように操作量をサンプル時刻ごと

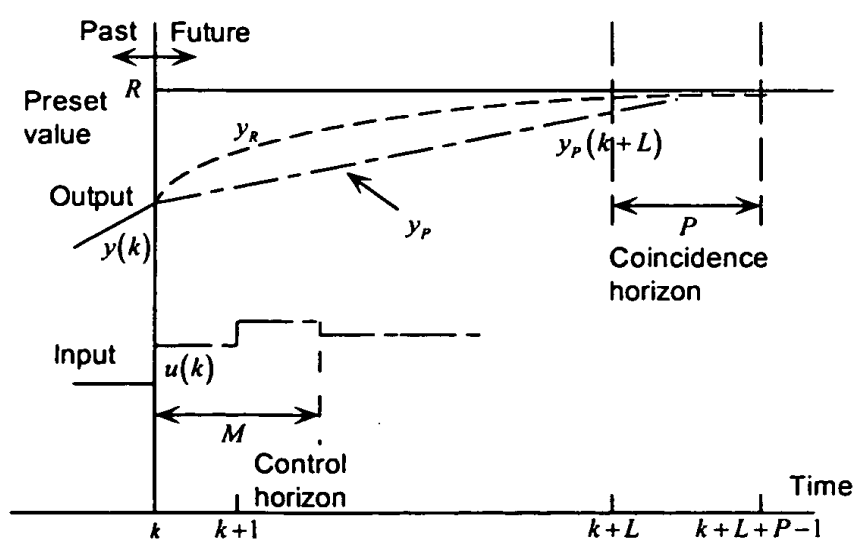

Fig. 7 Model Predictive Control Conception
に決め直していく”であり，その概念図を図７に示す. まず，現時刻 $k$ において $y(k)$ を観測し，y(k)を始 点として, 設定值 $R$ に近づく目標值の軌道

$$
y_{R}(k+j), \quad(L \leq k \leq L+P-1: \text { 評価区間) }
$$

を計算する。これは，出力を一気に設定値にもってい こうとするのではなく, ある滑らかな軌道に沿って最 終的に設定値に到達させる手法である.その軌道を参 照軌道と呼ぶ.

軌道を炔めた後, さらに, $y(k)$ を始点として $L$ ス テップ先の末来から $P$ ステップにわたる出力の値, $y_{P}(k+L), \cdots, y_{P}(k+L+P-1)$ をプロセスのモデルを 使って予測し, その評価区間で予測值が参照軌道に近 くなるように, $M$ ステップの入力 $u(k), \cdots, u(k+M$ -1) を計算する。計算した入力のうち, $u(k)$ のみを 用い, 時刻 $(k+1) に お い て$ 出力 $y(k+1)$ を再び観測 するというものである.これに適応の概念を導入した 手法が適応形予测制御である。ここで設計する適応形 予測制御系の目的は，設定した評価区間 $\left[N_{1}, N_{2}\right]$ にお いて, 先端位置角度の予测值 $\phi_{e p}$ が先端位置角度の目 標值 $\phi_{e d}$ と等しくなるようにすることである.これ は, 評価関数

$$
J\left(N_{1}, N_{2}\right)=\sum_{j=N_{1}}^{N_{2}}\left\{\phi_{e p}(k+j)-\phi_{e d}(k+j)\right\}^{2}
$$

を最小にする $\tau(k)$ は次式より得られる.

$$
\frac{\partial J\left(N_{1}, N_{2}\right)}{\partial \tau(k)}=0
$$

$3 \cdot 3$ 適応形予測制御の設計 まず, 線形離散時 間モデル式(11)に基づき, 先端位置角度 $\phi_{e}(k)$ を次式 により推定する。

$$
\widehat{\phi}_{e}(k)=Y^{T}(k-1) \sigma(k)
$$

ここで, $\widehat{\phi}_{e}(k)$ は先端位置角度の推定値, $\boldsymbol{\sigma}(k)$ はパラ メータベクトルの推定值である.

推定誤差 $\varepsilon(k)$ は, 式(11)と(14)より以下のように なる。

$$
\begin{aligned}
& \varepsilon(k) \triangleq \phi_{e}(k)-\bar{\phi}_{e}(k) \\
& \quad=Y^{T}(k-1)\{\sigma-\sigma(k)\}
\end{aligned}
$$

これは, 誤差方程式の一般形であるので, 種々の提案 されている適応アルゴリズムにより， $\varepsilon(k) \rightarrow 0(k \rightarrow$ の) が保証される(9).

次に, 現時点の推定䛊差と現時点より先の推定誤差 は一定と考え, $j$ 時点先の先端位置角度の予測値を次 式で推定する。

$$
\phi_{e p}(k+j)=\widehat{\phi}_{e}(k+j)+\varepsilon(k)
$$

ここで, 入力トルクの末来値は現時点の入力トルクと 等しく, 先端位置角度の末来值は現時点での予測值に 等しい,すなわち， 
$\tau_{1}(k+j)=\tau_{1}(k), \quad \phi_{e}(k+j)=\phi_{e p}(k+j)$

と仮定する.未来の推定パラメータと現在の推定パラ メータを一定と考えると, $j$ 時点先の予測值は次式で 得られる。

$$
\phi_{e p}(k+j)=g_{j}(k) \tau_{1}(k)+h_{j}(k)
$$
ただし，

$$
\left\{\begin{array}{l}
g_{j}(k)=\sum_{i=1}^{2 N}\left\{\hat{a}_{d i}(k) g_{j-i}(k)+\hat{b}_{d i}(k) m_{j-i}\right\} \\
h_{j}(k)=\sum_{i=1}^{2 N}\left\{\widehat{a}_{d i}(k) h_{j-1}(k)+\hat{b}_{d i}(k) n_{j-i}\right\}+\varepsilon(k) \\
g_{j}(k)=0 \quad(j \leq 0) \\
m_{j}=\left\{\begin{array}{l}
0:(j \leq 0) \\
1:(j \geq 1)
\end{array}\right. \\
h_{0}(k)=\phi_{e}(k), h_{-1}(k)=\phi_{e}(k-1) \\
h_{-2}(k)=\phi_{e}(k-2), h_{-3}(k)=\phi_{e}(k-3) \\
n_{j}=\left\{\begin{array}{l}
\tau_{1}(k+j-1):(j \leq 0) \\
0:(j \geq 1)
\end{array}\right.
\end{array}\right.
$$

$\widehat{a}_{d i}(k), \widehat{b}_{d i}(k):$ パラメータ $a_{d i}, b_{d i}$ の推定值 である。

Table 2 Physical Parameters

\begin{tabular}{|c|c|}
\hline Length $(\mathrm{m})$ & 0.5500 \\
\hline Linear Density $(\mathrm{kg} / \mathrm{m})$ & 0.6920 \\
\hline Young's Modulus $\left(\mathrm{N} / \mathrm{m}^{2}\right)$ & $1.255 \times 10^{13}$ \\
\hline Polar Moment of Inertia of $\mathrm{Area}\left(\mathrm{m}^{4}\right)$ & $2.667 \times 10^{-11}$ \\
\hline Damping Coefficient $\left(\mathrm{Nm}^{3} \mathrm{~s} / \mathrm{kg}\right)$ & $5.564 \times 10^{4}$ \\
\hline
\end{tabular}
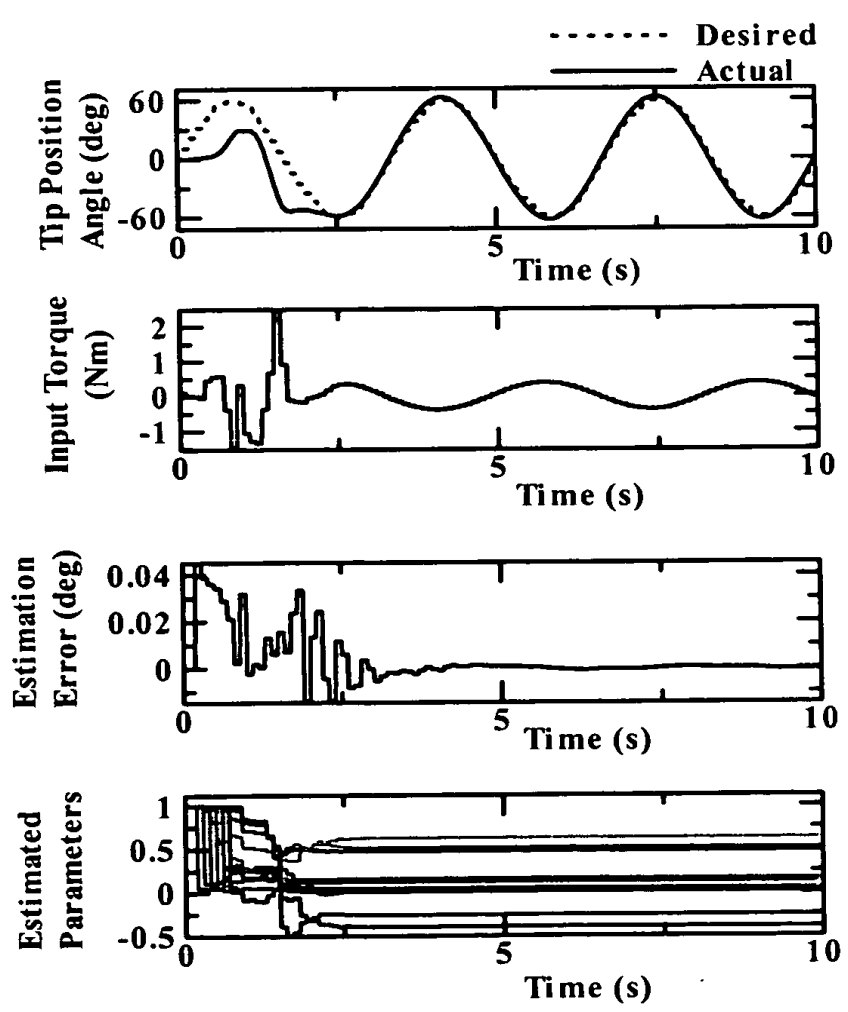

Fig. 8 Simulation Result
したがって，式（８）を満足する入力トルクは，次式で 与えられる。

$$
\tau_{1}(k)=\left\{\sum_{j=N_{1}}^{N_{2}} g_{j}^{2}(k)\right\}^{-1} \sum_{j=N_{1}}^{N_{2}} g_{j}(k)\left\{\phi_{e d}(k+j)-h_{j}(k)\right\}
$$

$3 \cdot 4$ シミュレーションおよび実験ここでは, 式 (5)に対して適応形予測制御系を構成し，その有効 性を計算機シミュレーションおよび実験により検証し た。用いたフレキシブルアームの物理パラメータを表 2 に示す. ペイロードは質量 $0.1979 \mathrm{~kg}$ の質点, サン

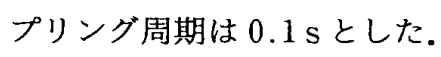

シミュレーション結果を図 8 と 9 , 実験結果を図 10 と 11 に示す。図 8 は評価区間を $[1,4]$ とし, 図 9 は評価区閒を $[1,10]$ とした場合のシミュレーション 結果である. 図 8 に扔ける推定パラメータの初期值 は,すべて 1 としてある.これにより推定されたパラ メータを図 9 の推定パラメータの初期值としている. 図 8 より，目標値によく追従していることがわかる. しかし，図 9 では，振幅・位相ともに目標値からの詋 差が見られる。これは，評価区間を広くすることによ り, 制御系の帯域幅が狭くなったためと考える.

次に, 実験結果図 10 と 11 から, 先端位置角度に振 動がみられる．また，推定パラメータも一定值に落ち 着いていない.これは, 実験装置の駆動部における摩 擦の変化により, パラメータの収束が十分でないこと
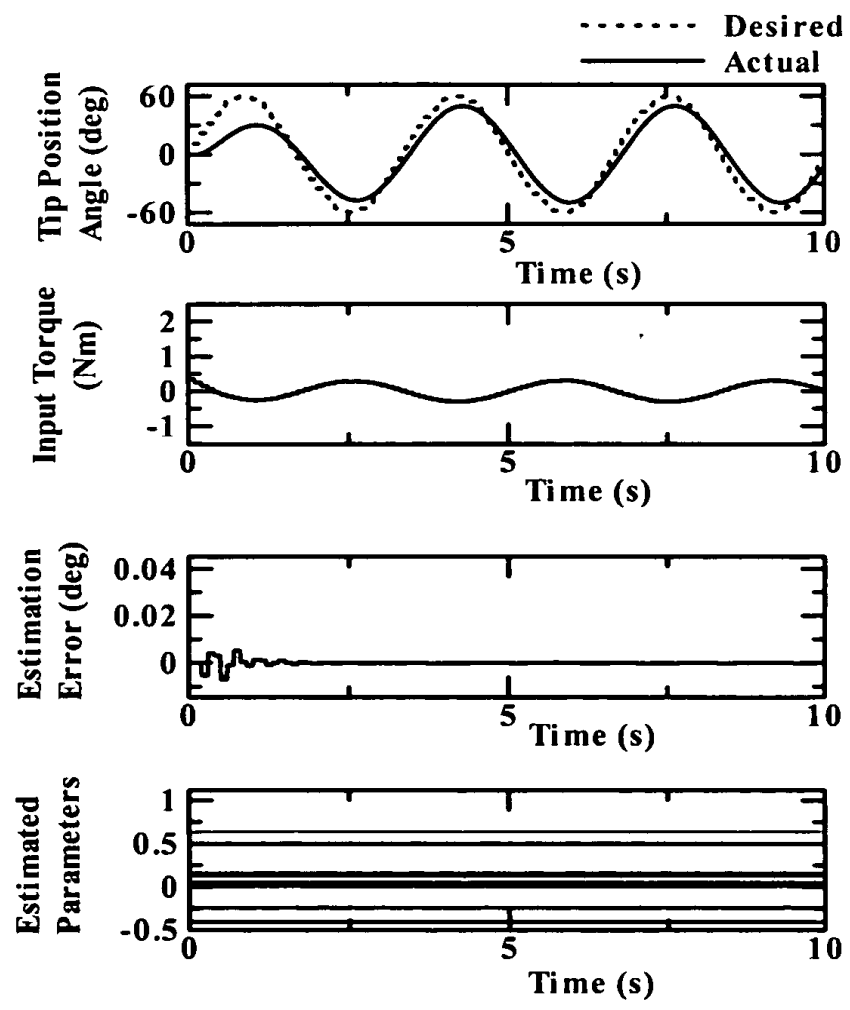

Fig. 9 Simulation Result 

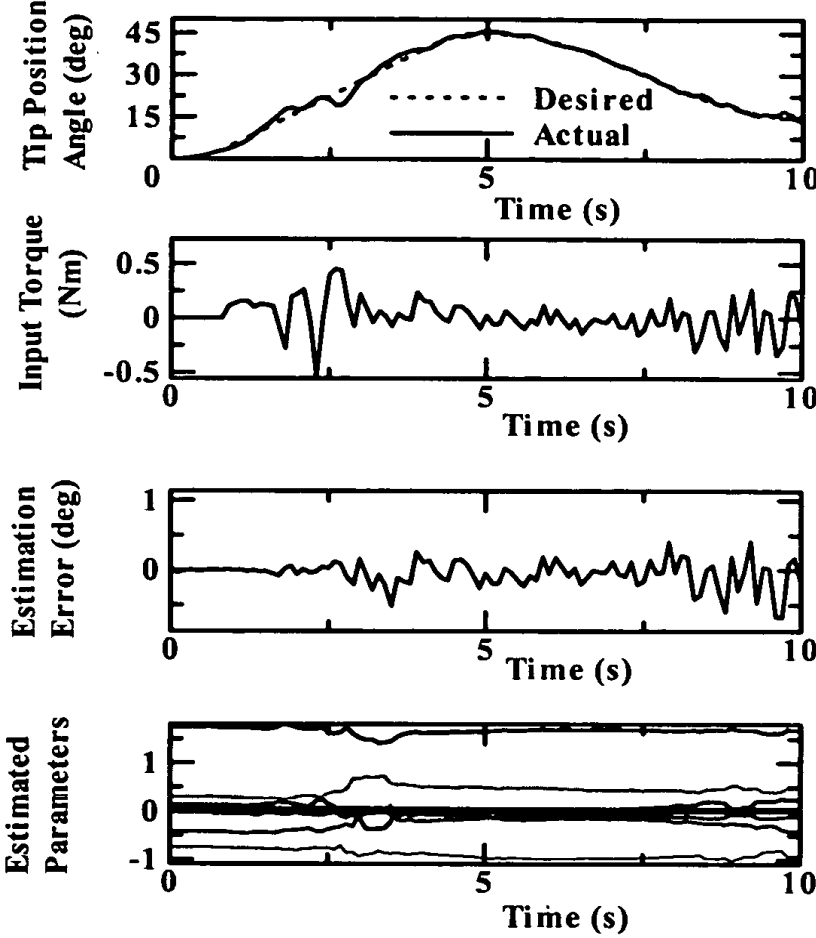

Fig. 10 Experimental Result
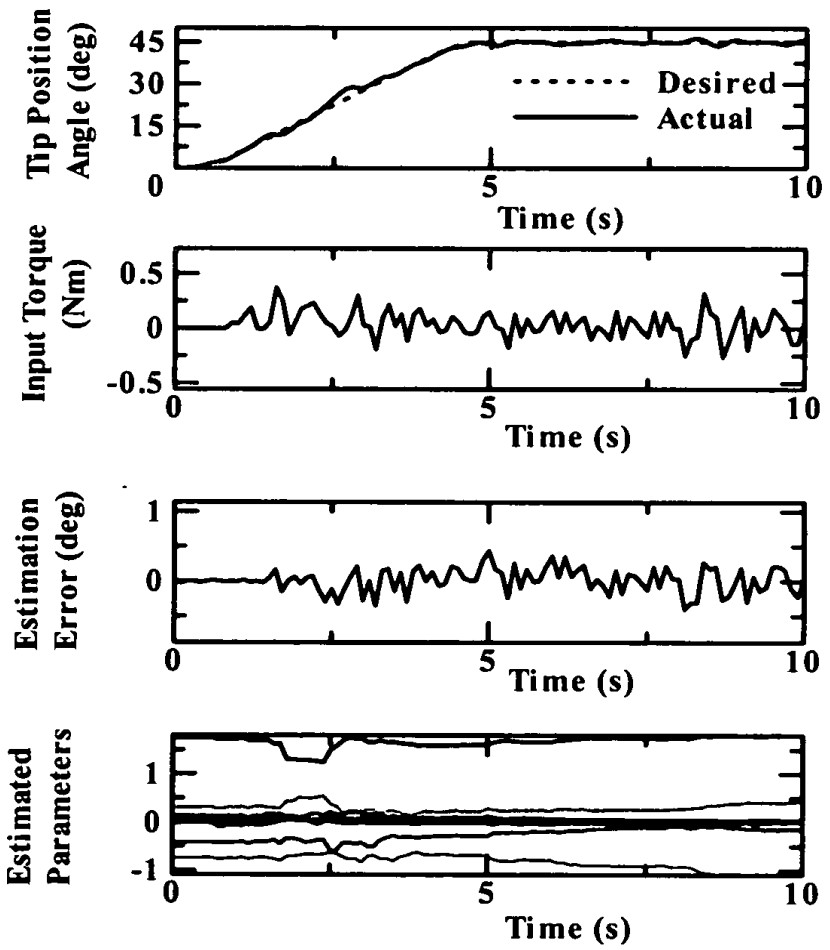

Fig. 11 Experimental Result

によるものと考えられる.しかし，駆動部の摩擦变化 があるにもかかわらず, 目標值への追従性は良好な結 果が得られている。より高速・高精度な追従性能を得 るためには，摩擦も考慮した制御系を設計する必要が あると考えられる。

また, 剛性の異なる 2 種類のアーム $\mathrm{A}$, アーム $\mathrm{B} に$
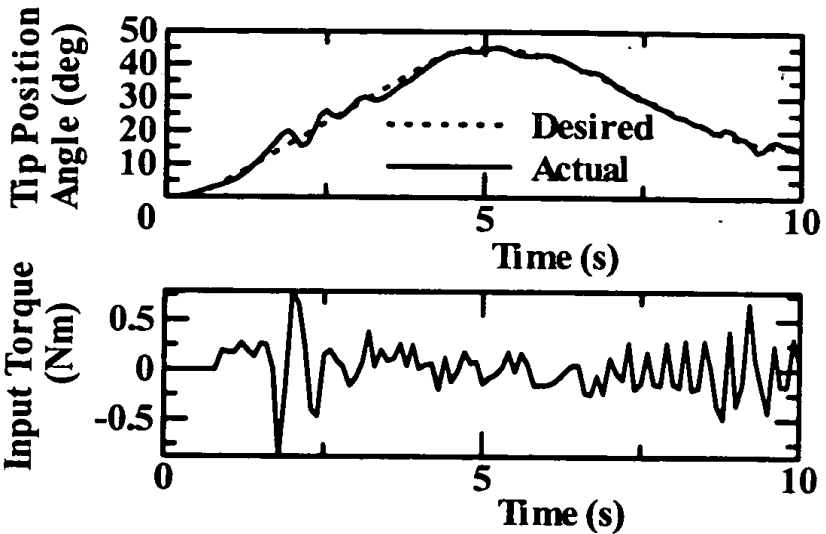

Fig. 12 Experimental Result (Arm A)
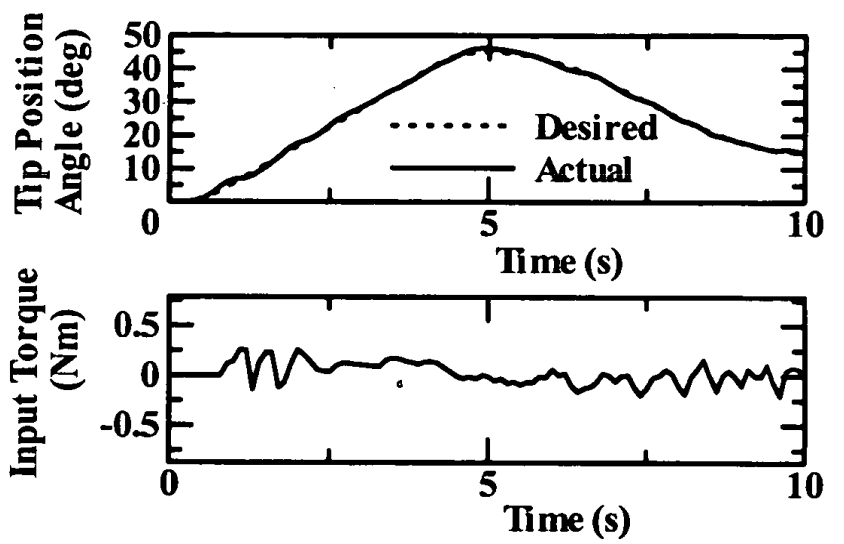

Fig. 13 Experimental Result (Arm B)

ついて，同じ条件の下で実験を行った。その結果を図 12 と 13 に示す.ここで,アーム $\mathrm{A}$ とアーム B の物 理パラメータは,アーム A が表 2 , アーム B が表 1 に示している.

実験結果図 12 と 13 から, 適応形予測制御を使うこ とにより，剛性の異なるアームに対しても同一のアル ゴリズムで制御可能であり, 本制御手法がフレキシブ ルアームの制御に適していることが裹付けられた。

なお，ここで対象とした実験装置に対しては，開ル ープ実験より二次モードまでが顕著に表れており，仮 想受動関節 2 個と仮想剛体リンク 3 本でモデリングす ることにより, 満足いく結果が得られた。

4.あと がき

本論文では，フレキシブルマニピュレータに対して 仮想受動関節モデルに基づき, 適応制御系と適応形子 測制御系を設計し，その有効性を 1 リンクフレキシブ ルマニピュレータにより検証した。

まず，仮想受動関節モデルの問題点のひとつである パラメー夕決定問題を, 適応制御手法を導入して解决 できることを示した。 また，角度制御実験により，そ 
の有効性を裹付けた。

次に，先端位置制御に対しては，ダイナミクスが, 非最小位相系となる場合でも適用可能な適応形予测制 御系を設計し，その有効性をシミュレーションと実験 により確認した。さらに, 剛性の異なる 2 種類のアー ムにおいても, 同条件で実験を行い有効性を確認し た。また，評価区間と帯域幅の関係について考察し た.

これらのことから，仮想受動関節モデルに基づく適 応形予測制御系が，フレキシブルマニピュレータの制 御において有用であることが確認できた。

なお，仮想受動関節モデルは低次近似モデルで，基 本的にはアームの顕著に表れるモード数に応じて仮想 受動関節数を設定する手法である.したがつて，他の 近似手法と同梯に省略した高次成分の影響が問題とな り，目標とする制御性能が達成できない場合には，さ らに仮想受動関節を増加させる必要がある.しかし， 関節の増加とともにパラメー夕数が増大し制御系設計 が複雑となる.これらに関しては今後の課題とした い.

\section{文献}

（1）日本ロボット学会編，フレキシブルマニピュレータ特集： 日本ロポット学会誌, 12-2 (1994), 169-223.

（2）大川不二夫・ほか 4 名, フレキシブルマニピュレータの 簡単化ディジタル制御, 機諭, 65-629, C, (1999), 154-160.

（3）福田敏男,フレキシブルロボットアームの制御, 機論, 51$468, \mathrm{C}(1985), 2140-2144$.

（4）土屋和雄・渡辺誠治，柔軟多体系の運動方程式のラグラ ンジェ形式による定式化，機論，59-468，C(1993)，411421.

（5）坂和愛幸・松野文倿, フレキシブル・アームのモデリン グと制御, 計測と制御, 25-1 (1988), 64-70.

(6) Sakawa, Y., Matuno, F. and Fukushima, S., Modeling and Feedback Control of a Flexible Arm, J. Rob. Systems, 2-4 (1985), 43-81.

（7）Jiang，Z.H.・内山勝・箱守京次郎，有限要素法近似モデ ルを用いた n リンク弾性ロボットの動的補償制御, 第 30 回自動制御連合講演会, (1987), 169-170.

（8）吉川恒夫・ほか1名,フレキシブルアームに対する仮想 受動関節モデルの有効性, 日本ロボット学会誌，17-2 (1999), 250-259.

（9）金井喜美雄，ロバスト適応制御入門，(1989)，オーム社.

(10) Spector, V. A. and Flashner, H., Modeling and Design Implications of Noncollocated Control Flexible Systems, 112 (1990-6), 186-193.

(11) Kaynak, O., Predictive Control of a Robotic Arm, IFAC Robot Control Karlsnihe, (1988), 213-218, FRG.

（12）大川不二夫・ほか 4 名, 水中マニピュレータの適応予測 制御, 機論, 61-583 (1995), 1072-1077. 